\title{
Effects of Chromium Supplementation on Chicken Broiler Growth and Carcass Characteristics
}

\author{
B. KRÓLICZEWSKA ${ }^{1}$, W. ZAWADZKIㄴ, T. SKIBA², D. MIŚTA ${ }^{1}$ \\ ${ }^{1}$ Department of Animal Physiology, Faculty of Veterinary Medicine, ${ }^{2}$ Department of Animal Products \\ Technology, Faculty of Food Science, Agricultural University of Wrocław, Poland
}

Received December 11, 2004

Accepted November 10, 2005

\begin{abstract}
Króliczewska B., W. Zawadzki, T. Skiba, D. Miśta: Effects of Chromium Supplementation on Chicken Broiler Growth and Carcass Characteristics. Acta Vet. Brno 2005, 74: 543-549.

The aim of this study was to evaluate the performance and carcass characteristics of broilers after chromium supplementation. One-day-old 90 Hubbard ISA male broiler chicks were divided into one control and two experimental groups. The control group was fed a basal diet, while the two experimental groups were fed a basal diet supplemented with chromium-enriched yeast in doses of 300 or $500 \mu \mathrm{g} \cdot \mathrm{kg}^{-1} \mathrm{Cr}$. Supplementation of $500 \mu \mathrm{g} \cdot \mathrm{kg}^{-1} \mathrm{Cr}$ increased body weight (BW), body weight gain (BWG), and also feed conversion ratio (FCR), $(p<0.05)$ compared to the dose of 300 $\mu \mathrm{g} \cdot \mathrm{kg}^{-1} \mathrm{Cr}$ and to the control diet. The dressing percentage was the highest $(75.6 \%)$ in the group fed $500 \mu \mathrm{g} \cdot \mathrm{kg}^{-1} \mathrm{Cr}$, and differed significantly $(p<0.05)$ compared to the control and $300 \mu \mathrm{g} \cdot \mathrm{kg}^{-1}$ Cr groups. The use of chromium yeast in the feeding of chickens caused a decrease of cholesterol level and the content in muscles. The largest differences were observed in breast muscles in the group fed $500 \mu \mathrm{g} \cdot \mathrm{kg}^{-1} \mathrm{Cr}$, where the content of cholesterol decreased by approximately $19 \%$ $(p<0.05)$. There were no significant differences between the groups in dry matter, protein and in organoleptic traits of the breast and leg muscles.
\end{abstract}

Cholesterol, $B W, B W G, F C R$

Chromium $(\mathrm{Cr})$ is a trace element that appears to be an essential micronutrient for animals and humans. Trivalent $\left(\mathrm{Cr}^{3+}\right)$ and hexavalent $\left(\mathrm{Cr}^{6+}\right)$ states are biologically active, but some differences in their metabolism are known. $\mathrm{Cr}^{6+}$ is more readily absorbed than $\mathrm{Cr}^{3+}$, but its toxicity is higher. In nature, chromium exists mostly in the $\mathrm{Cr}^{3+}$ form; it was observed to have antioxidant properties in vivo (Tezeuka et al. 1991) as well as to be an integral part of activating enzymes and maintaining the stability of proteins and nucleic acids (Borel and Anderson 1984; Anderson 1994). The primary role of Cr in metabolism is to potentiate the action of insulin through its presence in an organometallic molecule, called the glucose tolerance factor (GTF) (Anderson 1987; Sahin et al. 2001; Pechová et al. 2002; Sahin et al. 2003).

Insulin has been shown to increase the glucose and amino acid uptake into muscle cells, to regulate energy production, muscle tissue deposition, fat metabolism, and cholesterol utilization. If glucose cannot be utilized by body cells due to a low insulin level, it is converted into fat and stored in fat cells. Furthermore, if adequate amino acids cannot enter the cells, muscles cannot be built (Anderson 1987). Moreover, chromium deficiency can disrupt the carbohydrate and protein metabolisms, reduce the insulin sensitivity in peripheral tissues, and also impair the growth rate (Pagan et al. 1995; Sahin and Sahin 2002; Sahin et al. 2003).

Dietary chromium supplementation was found to accelerate body growth and to increase lean body mass in humans, experimental animals, and domestic livestock (Mertz 1993; Hasten et al.1997; Mow at et al. 1993). Dietary chromium supplementation was reported

Address for correspondence:

B. Króliczewska, PhD

Faculty of Veterinary Medicine Agricultural University of Wrocław

Department of Animal Physiology

C.K. Norwida St. 31, 50-375 Wrocław, Poland

Phone: + 48713205437

E-mail: bozena@ozi.ar.wroc.pl

http://www.vfu.cz/acta-vet/actavet.htm 
to have a positive effect on the growth rate and feed efficiency in growing poultry (Cupo and Donaldson 1987; Lien et al. 1999), particularly in birds reared under heat or cold stress (Sands and Smith 1999; Sahin et al. 2001; Sahin et al. 2003). Research with animals has confirmed that chromium from dietary organic complexes, such as chromium picolinate $(\mathrm{CrPic})$, chromium nicotinate $(\mathrm{CrNic})$ and high-chromium yeast, is absorbed more efficiently than chromium from inorganic forms. The reasons for the low availability of inorganic sources of $\mathrm{Cr}^{3+}$ are numerous and probably related to: the formation of insoluble chromic oxide; the binding to natural-chelating agents in feedstuffs (such as phytate); the interference by ionic forms of other elements as well as slow or no conversion of inorganic chromium to the bioactive form (Beitz and Horst 1997).

There is no specification for Cr requirements in poultry diets (NRC 1994), and most poultry diets are basically composed of plant-origin ingredients, usually low in $\mathrm{Cr}$ (Giri et al.1990).

The present study was conducted to determine the effects of different doses of chromium from chromium enriched yeast on the growth, body composition, dressing yield and meat quality of broiler chicken.

\section{Materials and Methods}

Animals, diets and experimental design

One-day-old male broiler chicks (90 Hubbard-ISA) were randomly assigned to 3 treatment groups. Each group was replicated 3 times with 10 birds per replicate pen in a battery brooder. All pens were equipped with feeders and waterers. The birds were fed either a control diet or the control diet supplemented with chelated chromium supplied from chromium yeast. Chelated chromium is a nicotinic acid-trivalent chromium-nicotinic acid axis with ligands of glutamic acid, glycine and cysteine. The process was conducted by growing yeast in rich chromium media (chromium chloride) in which the above three amino acids were bound. The type of yeast used was 1026 strain of viable culture of Saccharomyces cerevisiae at a concentration of $2.6 \times 10^{4}$ per gram. The yeast then died due to an increased temperature during the drying process (Alltech, Nicholasville, KY 40356, USA).

The birds were fed a starter diet until 21 days of age followed by a finishing diet from day 21 to day 42 . The ingredients and chemical composition of the starter and grower basal diets are shown in Table 1 . The basal diets were formulated with the use of NRC (1994) guideline, and contained 20-18.5\% crude protein (CP) and 12.13$12.55 \mathrm{MJkg}^{-1}$

\section{Metabolizable Energy (ME)}

The dietary treatments consisted of the supplementation of the basal diet with 0 (control), 300 or $500 \mu \mathrm{g} \cdot \mathrm{kg}^{-1}$ chromium, supplied from chromium yeast containing $1 \mathrm{~g}$ of $\mathrm{Cr}$ per $\mathrm{kg}$ of yeast. Small amounts of basal diets were first mixed with the respective amounts of chromium yeast, and then with a larger amount of the basal diet until the total amounts of the respective diets were homogeneous. Birds were kept in electrically heated batteries. Experimental diets were provided ad libitum.

Sample collection and laboratory analysis

All chickens per pen were weighed in groups at the beginning (on the $21^{\text {st }}$ day) and at the end of the experiment (42 $2^{\text {nd }}$ day). Body weight gain (BWG) was calculated from these data. The feed - consumed per pen - was recorded, and the feed convention ratio (FCR) was calculated. At the end of the experiment ten chickens per group were taken randomly as a representative sample and were slaughtered. The carcasses were dissected manually and the following criteria were recorded: carcass weight and dressing percentage (carcass weight as percentage of final body weight), weights of breast meat, legs (thigh + shank). These values were expressed as a percentage of the cold carcass weight. Basic chemical analysis of the dry matter (DM), crude protein (CP), crude ash (CA), crude fat (CF) and $\mathrm{pH}$ of muscles was conducted by conventional methods described by Pikul (1993). Cholesterol content in muscles was determined by the colorimetric method (Karkalas et al. 1982) by means of a commercially available kit (Boehringer Mannheim, Cat. No 0 139 050), and then it was read with the use of Beckman DU 640 Spectrometer. Colours of muscles were determined with the colorimetric method according to the accepted standards using Minolta Chromameter CR - 200. Results were presented in „Hunter Lab“ scale as L*, a*, b* (Uijttenboogaart et al. 1993; Ziołecki and Doruchowski 1989).

Traits of subjective meat quality were recorded by an organoleptic evaluation of roasted samples of breast and thigh meat of 10 chickens per group: a test panel consisting of five people judged the meat with regard to colour, flavour, taste, tenderness, juiciness and the tout ensemble, with grades from 1 (poor) to 5 (very good). Test panel evaluation of the muscles was performed in compliance with the Polish Standard PN-64/A-04022.

\section{Analyses and statistics}

The results obtained were processed through the program STATISTICA (data analysis software system) with the application of Windows version 5.0. All the numerical data were analyzed by one-way ANOVA to test the 
Table 1. Composition of the starter and grower diets for broiler

\begin{tabular}{|c|c|c|}
\hline Ingredients & Starter (1-21 d) & Grower (22-42 d) \\
\hline Corn & 37.50 & 51.00 \\
\hline Wheat & 22.00 & 12.00 \\
\hline Rape & & 30.00 \\
\hline Soybean meal & 25.48 & 18.00 \\
\hline Fodder meal & 3.00 & 5.00 \\
\hline Meat meal & 3.31 & 4.66 \\
\hline Vegetable oil & 5.00 & 3.00 \\
\hline Calcium carbonate & 0.20 & 0.30 \\
\hline Dicalcium phosphate & 1.95 & 1.50 \\
\hline Salt $(\mathrm{NaCl})$ & 0.30 & 0.30 \\
\hline DL-methionine & 0.26 & 0.24 \\
\hline Vitamin-mineral premix * & 1.00 & 1.00 \\
\hline \multicolumn{3}{|l|}{ Calculated analyses } \\
\hline Metabolizable energy (ME), $\mathrm{MJ} \mathrm{kg}^{-1}$ & 12.13 & 12.55 \\
\hline Crude protein $(\mathrm{CP}) \%$ & 20.00 & 18.50 \\
\hline Fibre $(\max ) \%$ & 4.00 & 4.00 \\
\hline Lysine & 1.22 & 1.14 \\
\hline Methionine + cystine & 0.92 & 0.86 \\
\hline Tryptophan & 0.21 & 0.19 \\
\hline Available Phoshorus & 0.40 & 0.40 \\
\hline Calcium & 1.00 & 0.85 \\
\hline Chromium analyzed value $\left(\mu \mathrm{g} \cdot \mathrm{kg}^{-1}\right)$ & 825 & 855 \\
\hline
\end{tabular}

effects of the dietary treatments. Significant differences of the obtained means were determined with the use of the Duncan multiple range test at the level of $p<0.05$. Statistical evaluation of the obtained data is presented in the tables as a mean $(\mathrm{x})$ and a standard deviation (SD).

\section{Results and Discussion}

The effects of supplemental chromium on the performance of broiler chickens are summarized in Table 2. All chickens were growing normally. Supplementation of $500 \mu \mathrm{g} \cdot \mathrm{kg}^{-1} \mathrm{Cr}$ either for 21 or 42 days increased BW, BWG, and also FCR $(p<0.05)$ compared to the dose of $300500 \mu \mathrm{g} \cdot \mathrm{kg}^{-1} \mathrm{Cr}$ and the control diet. A small supplement of yeast protein to the chicken diet (dilution 1:1000) should not affect the results among the experimental and control groups. Results of the present study are in agreement with the results of other authors. Lien et al. (1999) reported that dietary supplements of 1600 or 3 $200500 \mu \mathrm{g} \cdot \mathrm{kg}^{-1} \mathrm{Cr}$ as chromium picolinate markedly improved the weight gain of broiler chicken $(p<0.05)$. In addition, Sands and Smith (1999) also showed that the supplementation of chromium picolinate increased the growth rate without affecting the feed intake in broilers reared under environmental stress. Chen et al. (2001) indicated that $1 \mathrm{mg} / \mathrm{kg}$ chromium supplementation significantly improved the weight gain and food intake in turkeys from 9 to 18 weeks of age, but did not significantly influence performance in the period from 19 to 22 weeks of age. In other studies, supplemental chromium in the dose of $200,400,800$, and particularly of $1200 \mu \mathrm{g} \cdot \mathrm{kg}^{-1}$, resulted in the increase in body weight, feed intake, egg production and also feed efficiency of Japanese quails (S a hin et al. 2001). Moreover, Mooney and Cromwell (1997) suggest that chromium in the organic form as picolinate is more effective than chloride, and that $\mathrm{Cr}$ must be supplemented throughout the growing-finishing period to improve the carcass composition in swine. 
Table 2. Effects of supplementary chromium yeast on the body weight (BW), body weight gain (BWG) and feed conversion ratio (FCR) of chicken broilers from 1 to 42 days of age. * $\mathrm{O}=$ basal diet; $300=$ basal $\operatorname{diet}+300 \mu \mathrm{g} \cdot \mathrm{kg}^{-1} \mathrm{Cr}$ of diet; and $500=$ basal diet $+500 \mu \mathrm{g} \cdot \mathrm{kg}^{-1} \mathrm{Cr}$ of $\operatorname{diet}(\mathrm{n}=30),($ mean $\pm \mathrm{SD})$

\begin{tabular}{|c|c|c|c|}
\hline & \multicolumn{3}{|c|}{ Dietary Treatments* } \\
\hline & Control & 300 & 500 \\
\hline BW $(\mathrm{g})$ & & & $39.32 \pm 3.58$ \\
\hline $1 \mathrm{~d}$ & $40.09 \pm 3.15$ & $40.03 \pm 3.19$ & $655.88 \pm 54.91^{\mathrm{b}}$ \\
\hline $21 \mathrm{~d}$ & $647.22 \pm 42.15^{\mathrm{a}}$ & $638.50 \pm 70.88^{\mathrm{a}}$ & $2085.41 \pm 138.07^{\mathrm{b}}$ \\
\hline $42 \mathrm{~d}$ & $2009.16 \pm 102.68^{\mathrm{a}}$ & $1948.75 \pm 113.76^{\mathrm{a}}$ & $616.56 \pm 4.60^{\mathrm{b}}$ \\
\hline BWG (g) & & & $1429.53 \pm 18.40^{\mathrm{b}}$ \\
\hline 1 to $21 \mathrm{~d}$ & $607.13 \pm 9.04^{\mathrm{a}}$ & $598.47 \pm 7.68^{\mathrm{a}}$ & $2046.09 \pm 98.70^{\mathrm{b}}$ \\
\hline 22 to $42 \mathrm{~d}$ & $1362.94 \pm 16.04^{\mathrm{a}}$ & $1310.29 \pm 21.45^{\mathrm{a}}$ & $1.60 \pm 0.02$ \\
\hline 1 to $42 \mathrm{~d}$ & $1969.07 \pm 76.40^{\mathrm{a}}$ & $1908.72 \pm 89.46^{\mathrm{a}}$ & $1.81 \pm 0.06^{\mathrm{b}}$ \\
\hline FCR (g:g) & & & $1.72 \pm 0.03^{\mathrm{b}}$ \\
\hline 1 to $21 \mathrm{~d}$ & $1.57 \pm 0.03$ & $1.92 \pm 0.08^{\mathrm{a}}$ & \\
\hline 22 to $42 \mathrm{~d}$ & $1.87 \pm 0.04^{\mathrm{a}}$ & $1.81 \pm 0.02^{\mathrm{a}}$ & \\
\hline 1 to $42 \mathrm{~d}$ & $1.78 \pm 0.04^{\mathrm{a}}$ & & $1.17 \pm 0.02$ \\
\hline Mortality $\%)$ & & $1.12 \pm 0.01$ & \\
\hline 1 to $42 \mathrm{~d}$ & $1.14 \pm 0.01$ & & \\
\hline
\end{tabular}

Means in the same column with different superscript $a, b$ are significantly different $(p<0.05)$

Results of the slaughter analysis of broiler chickens fed a diet containing different chromium doses are presented in Table 3. The proportion of breast and leg muscles in the carcass was the highest in $300 \mu \mathrm{g} \cdot \mathrm{g}^{-1} \mathrm{Cr}$ group $(52.19 \%)$, followed by the group $500 \mu \mathrm{g} \cdot \mathrm{kg}^{-1}$ $\mathrm{Cr}(51.44 \%)$ and the control group $(51.39 \%)$. The dressing percentage was the highest $(75.67 \%)$ in the group fed $500 \mu \mathrm{g} \cdot \mathrm{kg}^{-1} \mathrm{Cr}$, and differed significantly $(p<0.05)$ compared to the control group and $300 \mu \mathrm{g} \cdot \mathrm{kg}^{-1} \mathrm{Cr}$. No information is available in literature on the effect of $\mathrm{Cr}$ on the carcass characteristics of market age broilers.

Table 3. Results of slaughter analysis of broilers fed a diet containing different chromium doses from 0 to 42 days of age. $* \mathrm{O}=$ basal diet; $300=$ basal diet $+300 \mu \mathrm{g} \cdot \mathrm{kg}^{-1} \mathrm{Cr}$ of diet; $500=$ basal diet $+500 \mu \mathrm{g} \cdot \mathrm{kg}^{-1} \mathrm{Cr}$ of diet $(\mathrm{n}=30)$, $($ mean $\pm \mathrm{SD})$

\begin{tabular}{|l|c|c|c|}
\hline \multirow{2}{*}{} & \multicolumn{3}{|c|}{ Supplementary Cr* levels $\left(\mu \mathrm{gg} \cdot \mathrm{kg}^{-1}\right)$} \\
\cline { 2 - 4 } & 0 & 300 & 500 \\
\hline Dressing percentage (\%) & $73.74 \pm 3.09 \mathrm{a}$ & $73.04 \pm 5.86 \mathrm{a}$ & $75.67 \pm 5.78_{\mathrm{b}}$ \\
\hline Breast muscles (\%) & $18.5 \pm 1.69$ & $20.04 \pm 1.64$ & $19.25 \pm 2.41$ \\
\hline Leg muscles (with bone) (\%) & $32.89 \pm 1.69$ & $32.15 \pm 1.41$ & $32.19 \pm 0.83$ \\
\hline
\end{tabular}

Means in the same row with different superscript $\mathrm{a}, \mathrm{b}$ are significantly different $(p<0.05)$

The estimations of chemical qualities of the breast and leg muscles of the chickens are presented respectively in Tables 4 and 5 .

Table 4. The chemical composition of breast muscles of broiler chicken (DM-dry matter, CP-crude protein, CFcrude fat, CA-crude ash), $* \mathrm{O}=$ basal diet; $300=$ basal diet $+300 \mu \mathrm{g} \cdot \mathrm{kg}^{-1} \mathrm{Cr}$ of diet; $500=$ basal diet $+500 \mu \mathrm{g} \cdot \mathrm{kg}^{-1} \mathrm{Cr}$ of diet $(\mathrm{n}=10),($ mean $\pm \mathrm{SD})$

\begin{tabular}{|c|c|c|c|c|c|}
\hline $\begin{array}{c}\text { Supplementary Cr* } \\
\text { levels }\left(\mu \mathrm{g} \cdot \mathrm{kg}^{-1}\right)\end{array}$ & $\begin{array}{c}\mathrm{DM} \\
\left(\mathrm{g} \cdot \mathrm{kg}^{-1}\right)\end{array}$ & $\begin{array}{c}\mathrm{CP} \\
\left(\mathrm{g} \cdot \mathrm{kg}^{-1}\right)\end{array}$ & $\begin{array}{c}\mathrm{CF} \\
\left(\mathrm{g} \cdot \mathrm{kg}^{-1}\right)\end{array}$ & $\begin{array}{c}\mathrm{CA} \\
\left(\mathrm{g} \cdot \mathrm{kg}^{-1}\right)\end{array}$ & $\mathrm{pH}$ \\
\hline 0 & $267.2 \pm 1.89$ & $237.6 \pm 1.51$ & $21.48 \pm 1.18^{\mathrm{a}}$ & $12 \pm 1.03$ & $5.632 \pm 0.007$ \\
\hline 300 & $259.1 \pm 1.35$ & $232.8 \pm 1.09$ & $18.34 \pm 1.05^{\mathrm{b}}$ & $12 \pm 1.00$ & $5.828 \pm 0.116$ \\
\hline 500 & $262.5 \pm 1.98$ & $232.8 \pm 1.48$ & $20.88 \pm 1.81^{\mathrm{a}}$ & $13 \pm 0.80$ & $5.850 \pm 0.141$ \\
\hline
\end{tabular}

Means in the same column with different superscript $\mathrm{a}, \mathrm{b}$ are significantly different $(p<0.05)$ 
Table 5. The chemical composition of leg muscles of broiler chicken (DM-dry matter, CP-crude protein, CF- crude fat, $\mathrm{CA}$-crude ash). $* \mathrm{O}=$ basal diet; $300=$ basal diet $+300 \mu \mathrm{g} \cdot \mathrm{kg}^{-1} \mathrm{Cr}$ of diet; $500=$ basal diet $+500 \mu \mathrm{g} \cdot \mathrm{kg}^{-1} \mathrm{Cr}$ of $\operatorname{diet}(\mathrm{n}=10),($ mean $\pm \mathrm{SD})$

\begin{tabular}{|c|c|c|c|c|c|}
\hline $\begin{array}{c}\text { Supplementary Cr* } \\
\text { levels }\left(\mu \mathrm{g} \cdot \mathrm{kg}^{-1}\right)\end{array}$ & $\begin{array}{c}\mathrm{DM} \\
\left(\mathrm{g} \cdot \mathrm{kg}^{-1}\right)\end{array}$ & $\begin{array}{c}\mathrm{CP} \\
\left(\mathrm{g} \cdot \mathrm{kg}^{-1}\right)\end{array}$ & $\begin{array}{c}\mathrm{CF} \\
\left(\mathrm{g} \cdot \mathrm{kg}^{-1}\right)\end{array}$ & $\begin{array}{c}\mathrm{CA} \\
\left(\mathrm{g} \cdot \mathrm{kg}^{-1}\right)\end{array}$ & $\mathrm{pH}$ \\
\hline 0 & $244.8 \pm 3.52$ & $188.0 \pm 4.79$ & $52.52 \pm 2.88$ & $7.9 \pm 0.66$ & $5.996 \pm 0.101$ \\
\hline 300 & $247.3 \pm 17.3$ & $187.0 \pm 2.00$ & $53.06 \pm 1.81$ & $9.9 \pm 0.85$ & $6.222 \pm 0.016$ \\
\hline 500 & $242.9 \pm 3.5$ & $181.4 \pm 2.88$ & $53.56 \pm 2.04$ & $9.5 \pm 0.81$ & $6.370 \pm 0.015$ \\
\hline
\end{tabular}

The use of chromium yeast in the feeding of chickens caused the lowering of the cholesterol level (Table 6) and fat content in muscles. The largest differences were observed in the case of breast muscles in the group fed $500 \mu \mathrm{g} \cdot \mathrm{kg}^{-1} \mathrm{Cr}$, where the content of cholesterol got smaller by approximately $19 \%(p<0.05)$ compared to the control group. Fat content in this group was lower (by approximately 10\%) only in breast muscles. No essential differences were observed in the protein level in breast muscles, and its content ranged from 23.76 to $23.28 \%$, and leg muscles $(18.80-18.14 \%$ ) (see Table 4 and 5).

Table 6. Total cholesterol content $(\mathrm{mg} / 100 \mathrm{~g})$ in muscles. $* \mathrm{O}=$ basal diet; $300=$ basal diet $+300 \mu \mathrm{g} \cdot \mathrm{kg}^{-1} \mathrm{Cr}$ of diet; $500=$ basal diet $+500 \mu \mathrm{g} \cdot \mathrm{kg}^{-1} \mathrm{Cr}$ of diet $(\mathrm{n}=10),($ mean \pm SD)

\begin{tabular}{|c|c|c|}
\hline $\begin{array}{c}\text { Supplementary } \\
\text { Cr* levels } \\
\left(\mu \mathrm{g} \cdot \mathrm{kg}^{-1}\right)\end{array}$ & Breast & Leg \\
\hline 0 & & $88.820 \pm 0.349^{\mathrm{a}}$ \\
\hline 300 & $70.480 \pm 0.725^{\mathrm{a}}$ & $79.900 \pm 0.115^{\mathrm{b}}$ \\
\hline 500 & $63.820 \pm 0.376^{\mathrm{c}}$ & $78.450 \pm 0.057^{\mathrm{b}}$ \\
\hline
\end{tabular}

Means in the same column with different superscript a, b, c are significantly different $(\mathrm{P}<0.05)$

When analyzing other parameters influencing the quality of meat, e.g. $\mathrm{pH}$, it was demonstrated that the $\mathrm{pH}$ value of the breast muscles was comprised in the range from 5.6 to 5.8, and in the leg muscles it oscillated from 5.9 to 6.3. Breast muscles possess larger quantities of glycogen with regard to their functionality; after slaughter, these muscles show lower $\mathrm{pH}$ than leg muscles, which was demonstrated in the present investigations. There were no essential changes in the dry matter of breast and leg muscles after the supplementation of chromium, although the dry matter content was higher in the breast muscles and oscillated from 25.91 to $26.72 \%$ in comparison with the leg muscles - oscillating between 24.29 and $24.73 \%$.

Thermally treated breast and leg muscles did not show any differences in organoleptic characteristics (Table 7). Breast muscles as well as leg muscles were characterized by significantly lower $(p<0.05)$ all colour parameters in the group fed $500 \mu \mathrm{g}^{\circ} \mathrm{kg}^{-1} \mathrm{Cr}$ (Table $8)$, compared to the remaining groups.

The addition of chromium yeast to the feed of broiler chickens did not cause any significant changes in the organoleptic parameters compared to the control group. Mean results of a sensory evaluation of tout ensemble for breasts amounted to 4.3 points, and for leg muscles - from 4.3 to 4.5 points.

In conclusion, the performance of broiler chicken and poultry meat quality depends mainly on the composition of diets. The results of the present study show that chromium supplementation of $500 \mu \mathrm{g} \cdot \mathrm{kg}^{-1} \mathrm{Cr}$ has a beneficial effect on the growth and quality of meat of broiler chickens; it particularly influences the cholesterol content. 
Table 7. Organoleptic evaluation of breast and leg muscles with grades from 1 (poor) to 5 (very good).* $\mathrm{O}=$ basal diet; $300=$ basal diet $+300 \mu \mathrm{g} \cdot \mathrm{kg}^{-1} \mathrm{Cr}$ of diet; $500=$ basal diet $+500 \mu \mathrm{g} \cdot \mathrm{kg}^{-1} \mathrm{Cr}$ of diet. $(\mathrm{n}=10)$

\begin{tabular}{|c|c|c|c|c|c|c|}
\hline $\begin{array}{c}\text { Supplementary } \\
\text { Cr* levels } \\
\left(\mu \mathrm{g} \cdot \mathrm{kg}^{-1}\right)\end{array}$ & Colour & Flavour & Taste & Tenderness & Juiciness & Tout ensemble \\
\hline $0 \mathrm{~B}$ & 4.3 & 4.2 & 4.1 & 3.7 & 3.7 & 4.3 \\
\hline $300 \mathrm{~B}$ & 4.6 & 4.4 & 4.3 & 3.7 & 3.7 & 4.3 \\
\hline $500 \mathrm{~B}$ & 4.5 & 4.4 & 4.1 & 3.8 & 3.8 & 4.3 \\
\hline $0 \mathrm{~L}$ & 4.5 & 4.6 & 4.3 & 4.1 & 4.1 & 4.5 \\
\hline $300 \mathrm{~L}$ & 4.5 & 4.5 & 4.1 & 4.2 & 4.2 & 4.5 \\
\hline $500 \mathrm{~L}$ & 4.5 & 4.2 & 4.2 & 4.2 & 4.0 & 4.2 \\
\hline
\end{tabular}

B - Breast muscle, L - Leg muscle

Table 8 . Colorimetric evaluation of muscle colour.* $\mathrm{O}=$ basal diet; $300=$ basal diet $+300 \mu \mathrm{g}^{*} \mathrm{~kg}^{-1} \mathrm{Cr}$ of diet; 500 $=$ basal diet $+500 \mu \mathrm{g} \cdot \mathrm{kg}^{-1} \mathrm{Cr}$ of diet $(\mathrm{n}=30),($ mean $\pm \mathrm{SD})$

\begin{tabular}{|c|c|c|c|c|}
\hline \multirow{2}{*}{ Groups } & \multirow{2}{*}{ Colour } & \multicolumn{3}{|c|}{ Supplementary Cr* levels $\left(\mu \mathrm{g}^{1} \mathrm{~kg}^{-1}\right)$} \\
\cline { 3 - 5 } & & 0 & 300 & 500 \\
\hline Breast muscle & $\mathrm{L}$ & $71.06 \pm 1.08^{\mathrm{a}}$ & $74.06 \pm 2.57^{\mathrm{a}}$ & $63.82 \pm 2.40^{\mathrm{b}}$ \\
& $\mathrm{a}$ & $3.12 \pm 0.30^{\mathrm{a}}$ & $3.70 \pm 0.40^{\mathrm{a}}$ & $2.16 \pm 0.14^{\mathrm{b}}$ \\
& $\mathrm{b}$ & $25.20 \pm 0.98^{\mathrm{a}}$ & $26.48 \pm 1.09^{\mathrm{a}}$ & $22.5 \pm 1.44^{\mathrm{b}}$ \\
\hline Leg muscle & $\mathrm{L}$ & $70.16 \pm 0.94^{\mathrm{a}}$ & $69.20 \pm 0.34^{\mathrm{a}}$ & $64.52 \pm 0.40^{\mathrm{b}}$ \\
& $\mathrm{a}$ & $16.60 \pm 2.33$ & $14.28 \pm 1.26$ & $14.40 \pm 0.86$ \\
& $\mathrm{~b}$ & $26.36 \pm 0.76^{\mathrm{a}}$ & $26.54 \pm 0.29^{\mathrm{a}}$ & $24.02 \pm 0.50^{\mathrm{b}}$ \\
\hline
\end{tabular}

Means in the same row with different superscript $\mathrm{a}, \mathrm{b}$ are significantly different $(P<0.05)$

${ }^{1} \mathrm{~L}$ - lightness scale 0 -100, a - redness, b-yellow

\section{Účinek aplikace chrómu na růst a užitkovost brojlerů kuřat}

Cílem studie bylo vyhodnotit růst a užitkovost brojlerů kuřat po aplikaci chrómu. Devadesát jednodenních kuřat Hubbard ISA bylo rozděleno na kontrolní a dvě experimentální skupiny. Kontrolní skupina byla krmena základní krmnou směsí, zatímco dvě experimentální skupiny byly krmeny základní krmnou směsí s přídavkem chrómu v obohacených kvasnicích v dávkách 300 nebo $500 \mu \mathrm{g} \cdot \mathrm{kg}^{-1} \mathrm{Cr}$. Přídavek $500 \mu \mathrm{g} \cdot \mathrm{kg}^{-1} \mathrm{Cr}$ zvýšil BW, BWG a také FCR $(p<0,05)$ ve srovnání s dávkou $300 \mu \mathrm{g} \cdot \mathrm{kg}^{-1}$ a s kontrolním krmivem. Nejvyšší výtěžnost $(75.6 \%)$ byla ve skupině krmené $500 \mu \mathrm{g} \cdot \mathrm{kg}^{-1} \mathrm{Cr}$, která se významně lišila $(p<0,05)$ od kontrolní skupiny a skupiny krmené $300 \mu \mathrm{g} \cdot \mathrm{kg}^{-1} \mathrm{Cr}$. Využití chrómem obohacených kvasnic v krmení kuřat snížilo koncentraci cholesterolu a obsah tuku ve svalovině. Největší rozdíly byly zjištěny u prsní svaloviny ve skupině krmené $500 \mu \mathrm{g} \cdot \mathrm{kg}^{-1} \mathrm{Cr}$, kde se obsah cholesterolu snížil přibližně o $19 \%$ ( $p<0,05)$. Nebyly zjištěny žádné významné rozdíly v obsahu sušiny, proteinů a v organoleptických vlastnostech prsních a stehenních svalů.

\section{References}

ANDERSON RA 1987: Chromium in animal tissues and fluids. Trace elements in human and animal nutrition. In: Mertz W. Ed. Vol. 1, Academic Press, New York, pp. 225-244

ANDERSON RA 1994: Stress effects on chromium nutrition of humans and farm animals. In: Lyons TP, Jacques K.A., Ed. Biotechnology in Feed Industry. Nottingham, England: Univ. Press, pp. 267-274

BEITZ DC, HORST RL 1997: Introduction and metabolic role of chromium. In: The Role of Chromium in Animal Nutrition. Committee on Animal Nutrition Board on Agriculture National Research Council, J.L. Sell, Ed National Academy Press, Washington, D.C. pp. 6-14 
BOREL JS, ANDERSON RA 1984: Chromium. In: Biochemistry of the Essential Ultratrace Elements, E. Frieden, Ed. New York, Plenum Press, pp. 175-199

CHEN KL, LU TF, CHIOU PW 2001: Effects of chromium nicotinate on performance, carcass characteristics and blood chemistry of growing turkeys. Br Poult Sci 7: 399-404

CUPO MA, DONALDSON WE 1987: Chromium and vanadium effects on glucose metabolism and lipid synthesis in the chick. Poult Sci 66: 120-126

HASTEN DL, HEGSTED M, KEENAN MJ, MORRIS S 1997: Effects of various forms of dietary chromium on growth and body composition in the rat. Nutrition Res 17: 283-294

GIRI J, USHA KA, SUNITA T 1990: Evaluation of the selenium and chromium content of plant foods. Plant Foods Hum Nutr 40: 49-59

LIEN TF, HORNIG YM, YANG KH 1999: Performance, serum characteristics, carcass traits and lipid metabolism of broilers as affected by supplement of chromium picolinate. Br Poult Sci 40: 357- 363

KARKALAS J, DONALD E, CLEGG KM 1982: Cholesterol content of poultry meat and cheese determined by enzymatic and gas-liquid chromatography methods. J Food Technol 17: 281-283

MERTZ W 1993: Chromium in human nutrition. A review. J Nutr 123: 626-633

MOONEY KW, CROMWELL GL 1997: Efficacy of chromium picolinate and chromium chloride as potential carcass modifiers in swine. J Anim Sci 75: 2661-2671

MOWAT DN, CHANG X, YANG WZ 1993: Chelated chromium and bovine respiratory diseases vaccines for stressed feeder calves. Can J Anim Sci 73: 49-55

NRC (National Research Council), 1994: Nutrient Requirements of Poultry, 9th Ed. Natl. Academy Press, Washington, DC

PAGAN JD, JACKSON SG, DUREN SE 1995: The effect of chromium supplementation on metabolic response to exercise in thoroughbred horses. In: Biotechnology in Feed Industry: Proceedings of Alltech's Eleventh Annual Symposium. Lyons TP, Jacques KA. Ed. Nottingham, UK: Nottingham University Press, pp. 249-256

PECHOVÁ A, ILLEK J, ŠINDELÁŘ M, PAVLATA L 2002: Effects of Chromium Supplementation on growth rate and metabolism in fattening bulls. Acta Vet Brno 71: 535-541

PIKUL J 1993: Technological estimation of material and products of poultry industry. AR, Poznań (in Polish)

POLISH STANDARD PN-64/A-04022. Methods of sensory analysis. Analysis of particular characteristics and the over-all quality by scoring methods. Principles of the construction of Scoring Models for Individual Food Products (in Polish)

SAHIN K, KÜCÜK O, SAHIN N, OZBEY O 2001: Effects of dietary chromium picolinate supplementation on egg production, egg quality and serum concentrations of insulin, corticosterone, and some metabolites of Japanese quails. Nutr Res 21: 1315-1321

SAHIN K, SAHIN N 2002: Effects of chromium picolinate and ascorbic acid dietary supplementation on nitrogen and mineral excretion of laying hens reared in a low ambient temperature (7oC). Acta Vet Brno 71: 183-189

SAHIN K, SAHIN N, KÜCÜK O 2003: Effects of chromium and ascorbic acid supplementation on growth, carcass traits, serum metabolites, and antioxidant status of broiler chickens reared at a high ambient temperature $(32 \mathrm{oC})$. Nutr Res 23: 225-238

SANDS JS, SMITH MO 1999: Broilers in heat stress conditions: effects of dietary manganese proteinate or chromium picolinate supplementation. J Appl Poult Res 8: 280-287

TEZEUKA M, MOMIYAMA K, EDANO T, OKADA S 1991: Protective effect of chromium (III) on acute lethal toxicity of carbon tetrachloride in rats and mice. J Inorg Biochem 42: 1-8

UIJTTENBOOGAART TG, TRZISZKA TL, SCHEREURS FJG 1993: Cryoprotectant effects during short-time frozen storage of chicken myofibrillar protein isolates. J Food Sci 58: 274-277

ZIOŁECKI L, DORUCHOWSKI W 1989: Procedure of estimation of slaughtering value of poultry. Ed. COBRD Poznań, 1 p. 
